\title{
Global Analysis of Durable Policies for Free-Flowing River Protections
}

\author{
Denielle Perry ${ }^{1, *}$, Ian Harrison ${ }^{2}{ }^{(}$, Stephannie Fernandes ${ }^{1}{ }^{\mathbb{C}}$, Sarah Burnham ${ }^{1}$ and Alana Nichols ${ }^{1}$ \\ 1 School of Earth and Sustainability, Northern Arizona University, Flagstaff, AZ 86011, USA; \\ sdf94@nau.edu (S.F.); seb392@nau.edu (S.B.); amn367@nau.edu (A.N.) \\ 2 Moore Center for Science, Conservation International, Arlington, VA 22202, USA; iharrison@conservation.org \\ * Correspondence: denielle.perry@nau.edu; Tel.: +1-(928)-523-0361
}

check for updates

Citation: Perry, D.; Harrison, I.; Fernandes, S.; Burnham, S.; Nichols, A. Global Analysis of Durable Policies for Free-Flowing River Protections. Sustainability 2021, 13, 2347. https://doi.org/10.3390/su13042347

Academic Editor:

Jose Navarro Pedreño

Received: 29 January 2021

Accepted: 16 February 2021

Published: 22 February 2021

Publisher's Note: MDPI stays neutral with regard to jurisdictional claims in published maps and institutional affiliations.

Copyright: (c) 2021 by the authors. Licensee MDPI, Basel, Switzerland. This article is an open access article distributed under the terms and conditions of the Creative Commons Attribution (CC BY) license (https:// creativecommons.org/licenses/by/ $4.0 /)$.

\begin{abstract}
Freshwater ecosystems are poorly represented in global networks of protected areas. This situation underscores an urgent need for the creation, application, and expansion of durable (longterm and enforceable) protection mechanisms for free-flowing rivers that go beyond conventional protected area planning. To address this need, we must first understand where and what types of protections exist that explicitly maintain the free-flowing integrity of rivers, as well as the efficacy of such policy types. Through policy analysis and an in-depth literature review, our study identifies three main policy mechanisms used for such protections: (1) River Conservation Systems; (2) Executive Decrees and Laws; and (3) Rights of Rivers. We found that globally only eight counties have national river conservation systems while seven countries have used executive decrees and similar policies to halt dam construction, and Rights of Rivers movements are quickly growing in importance, relative to other protection types. Despite the current extent of protection policies being insufficient to tackle the freshwater and biodiversity crises facing the world's rivers, they do provide useful frameworks to guide the creation and expansion of protections. Ultimately, as countries act on global calls for protections, policy mechanisms must be tailored to their individual social and ecological geographies.
\end{abstract}

Keywords: freshwater biodiversity conservation; hydropower development; rights of rivers; riverine ecosystem services; Wild and Scenic Rivers

\section{Introduction}

Freshwater is essential for human and non-human life systems [1,2], as evidenced by the fact that most advanced societies developed near rivers [3,4]. Yet, freshwater counts only as $0.01 \%$ of the world's water and occupies just $0.8 \%$ of Earth's surface [5]. Within freshwater ecosystems, around $9.5 \%$ (very possibly more) of all described animal species are found, including one-third of all vertebrates [6,7]. The ecosystem services offered by freshwater systems are extremely valuable and projected to be worth around US $\$ 4$ trillion annually [8]. Free-flowing rivers (i.e., those rivers or segments or rivers whose flow is not obstructed or diverted in such a way as to impede connectivity) are important freshwater ecosystems, as they provide migration routes for aquatic and riparian species, allow for the transportation of sediment and nutrients, enable groundwater recharge, and mitigate flooding, among a myriad of other services $[7,9]$. River floodplains and estuaries are ranked as the most productive ecosystems in the world that provide benefits and goods to human communities $[10,11]$.

Yet, the 247 species monitored in the Living Planet Index for Migratory Freshwater Fish showed an overall average decrease of 76\% between 1970 and 2016, with habitat degradation, alteration, and loss accounting for about half of the threats to these species [12]. Freshwater ecosystems are among the most threatened on Earth, with wetland extent having declined by almost 70\% since 1900 and, freshwater vertebrate populations having declined, on average, by 84\% between 1970 and 2016 [13]. Dams and water diversions 
are responsible for much of the decline of freshwater habitat. Large dams provide energy, irrigation, flood control, and municipal water security, by modifying the flow of the rivers [14]. However, the benefits of these edifices come at the cost of a variety of complex and cascading negative economic, social, and environmental consequences [15-17]. For instance, dams create artificial lakes, thereby, disrupting hydrologic connectivity [14-17]. These disruptions result in alterations to the natural transport of sediments, unnatural variations in temperature and water flows [9,10,17], biodiversity loss, impediment of fish migrations [18-20], degradation of water quality, displacement of riverine communities [16,21-23], and complex changes in emissions of climate changing greenhouse gases through increased $\mathrm{CO}_{2}$ emissions from concrete, and methane emissions from decomposing organic matter [24-26]. At present, there are an estimated 2.8 million dams in the world and roughly 3700 major dams being constructed or planned for the near future $[27,28]$. With less than one-third of the world's rivers remaining free-flowing, durable protections that safeguard rivers from dam development are imperative to protect the riverine ecosystems and their services $[7,27]$. Moreover, policies that prohibit dam development are vital as they ensure connectivity and its associated benefits, thus, avoiding the need for costly restoration efforts [29].

In 2020, the need for free-flowing river protections was made explicit in a motion, submitted by multiple NGOs, to the International Union for the Conservation of Nature (IUCN), calling for the identification, restoration, and protection of free-flowing rivers or stretches and their associated ecosystems. That motion was overwhelming approved by the IUCN membership ( $91 \%$ of states, government agencies, and political and/or economic integration organizations; and $88 \%$ national and international nongovernmental organizations and Indigenous Peoples' Organizations) and is now accepted as IUCN Resolution WCC-2020-Res-008-EN [30]. Legislation for protected areas (PAs) does exist in the world, however, in the history of environmental governance, PAs were created to preserve or conserve specific ecosystems and their biodiversity [31], with terrestrial ecosystems historically the primary focus of concern and rivers serving as boundaries or playing ancillary roles [31-33]. Globally, $70 \%$ of rivers are left outside PA protection and only $11.1 \%$ are entirely protected [34]. Incidentally, PAs fail to capitalize on their full potential to conserve freshwater biodiversity [34-38]. PAs not explicitly established to maintain the free-flow of rivers are also subject to a lack of or change in their governing legislation that may allow for the damming of a river [38]. Notably, more than 1200 dams exist within PAs and more than 500 are under construction or planned in the next two decades [38].

The objective of this study is to identify the range of river protection types and their distributions globally, as well as to assess the efficacy of their implementation to maintain the free-flowing integrity of rivers. This information can help guide further progress in expanding durable protections for the world's endangered and vital riverine ecosystems. In this study, we define durable protections as policies that are enforceable and aim for long-term (ideally permanent) protections of rivers from dams and other developments that obstruct a river's flow, reduce connectivity, and degrade riverine ecosystems. To that end, we conducted a policy and discourse analysis to identify the types and efficacy of protections at the national level that patently prohibit the development of dams for the maintenance of the river's free-flowing nature. We also performed a spatial and temporal analysis of policy types to reveal trends in policy creation and application around the globe. Our study suggests that there are three main policy mechanisms that provide durable free-flowing river protections: (1) River Conservation Systems; (2) Executive Decrees and National Laws; and (3) Rights of Rivers. Our findings further reveal a growing movement to create and implement protections across all policy types, albeit with differing levels of protection. Ultimately, with only 17 of roughly 195 countries in the world today offering such policies, there is much room to expand durable river protections to meet the pressing conservation needs of our freshwater ecosystems. 


\section{Materials and Methods}

We conducted a global comparative policy and discourse analysis of protections that prohibit the development of dams that impair the free-flowing nature of rivers. To conduct these analyses, we first searched for both policy documents and gray literature from every country to identify protection policies emanating from the national and/or executive level of government. We searched for published materials in the Web of Science and Google Scholar using search terms "free-flowing" OR "free-flowing rivers" OR "anti-dam" OR "dam free" OR "rios livres" (Portuguese) OR "ríos libres" (Spanish) OR "river protection policy" OR "human rights for rivers" OR "river conservation". These searches were supplemented by more general web searches through the Google search engine to locate policy documents and gray literature. The presence of dams in a river did not preclude those rivers from our searches because our analysis was focused on how policies can prevent further reduction of free-flow. In fact, a specific objective of this study was to ascertain how different polices address the presence of dams within any part of the river. We also analyzed the Constitute Project's constitutional database [39] to find evidence of river protections. The database search included relevant terms such as: "water" (number of results, $\mathrm{n}=107)$; "conservation" ( $\mathrm{n}=90)$; "rivers" $(\mathrm{n}=30)$; "ecosystem" ( $\mathrm{n}=9)$; and "riparian," "freshwater", and "aquatic" ( $\mathrm{n}=2$ for each). From these searches, we compiled a unique database containing location, river name(s), national governance structure, policy type, year established, policy descriptions, and associated discourse related to the policy application and efficacy. We analyzed this database to reveal the types of policies that exist, how they function, and the spatial and temporal trends in their creation and application around the globe.

\section{Results}

Database analyses revealed three main policy types: national river conservation systems, decrees and other executive policies, and Rights of Rivers. The following section provides descriptions of the characteristics of each policy including their similarities and distinctions within these three categories as they are applied around the globe.

\subsection{National River Conservation Systems}

The National Wild and Scenic Rivers System of the United States of America (U.S.) is the first national river conservation system created in the world. This system, mandated by the Wild and Scenic Rivers Act of 1968 (WSRA) (Public Law 90-542; U.S.C 1271 et seq.) [40], was established to strike a balance between dam development and river conservation interests after decades of large dam development that altered the vast majority of U.S. rivers. This law mandates the protection of the free-flow and Outstandingly Remarkable Values (ORVs) of rivers, or segments of rivers, found to be regionally and nationally significant for conservation purposes. These ORVs (e.g., Fish, Wildlife, Geologic, Historic, Cultural, Recreation, Scenic, and Other) can be thought of as riverine ecosystem services. Thus, once designated, a Wild and Scenic River (WSR) receives a Comprehensive River Management Plan (CRMP) that outlines how to protect and enhance the river's free-flowing nature, water quality, and ecosystem services in perpetuity. Notably, upon designation, no dams are permitted in the protected corridor [41,42].

In over 52 years since the establishment of the WSRA in October 1968, 226 distinct designations have been made to protect segments of rivers and their tributaries across the country. In addition, there are over 3200 rivers potentially eligible for designation on the Nationwide Rivers Inventory and countless others that have been found eligible in recent decades [43]. Ongoing advocacy efforts aim to increase the number of protected rivers to meet different conservation priorities. The WSRA has also provided a policy framework for other national river conservation systems around the world. Our research shows seven other countries have established such systems, and China is currently piloting a study for the potential creation of a system (See Table 1 and Figure 1). Australia attempted but failed to pass a bill that would establish a national system. 
Table 1. Globally, since 1968, eight national river conservation systems have been created to protect 1178 rivers, with one additional system in study phase.

\begin{tabular}{cccc}
\hline Country & Policy Name & Year & Protected Rivers \\
\hline United States & Wild and Scenic Rivers Act of 1968 & 1968 & $\begin{array}{c}226 \text { designations } \\
3200+\text { eligible }\end{array}$ \\
\hline New Zealand & Wild and Scenic Rivers Amendment & 1981 & 15 \\
\hline Canada & Canadian Heritage Rivers System & 1984 & 39 designated \\
& Protection Plan for Watercourses & nominated \\
Norway & (compendium of several Acts) & 388 \\
\hline Finland & Rapids Protection Act & 2005,2009 & 1993, \\
\hline Sweden & Swedish Environmental Code of 1999 & 1987 & 1999 \\
\hline Spain & River Protection Reserves & 2015 & 135 reserves \\
\hline Mexico & National Water Reserves for the Environment Program & 2012 & 294 river basins \\
\hline China & National Protected Rivers System & Study phase & 1 \\
\hline
\end{tabular}

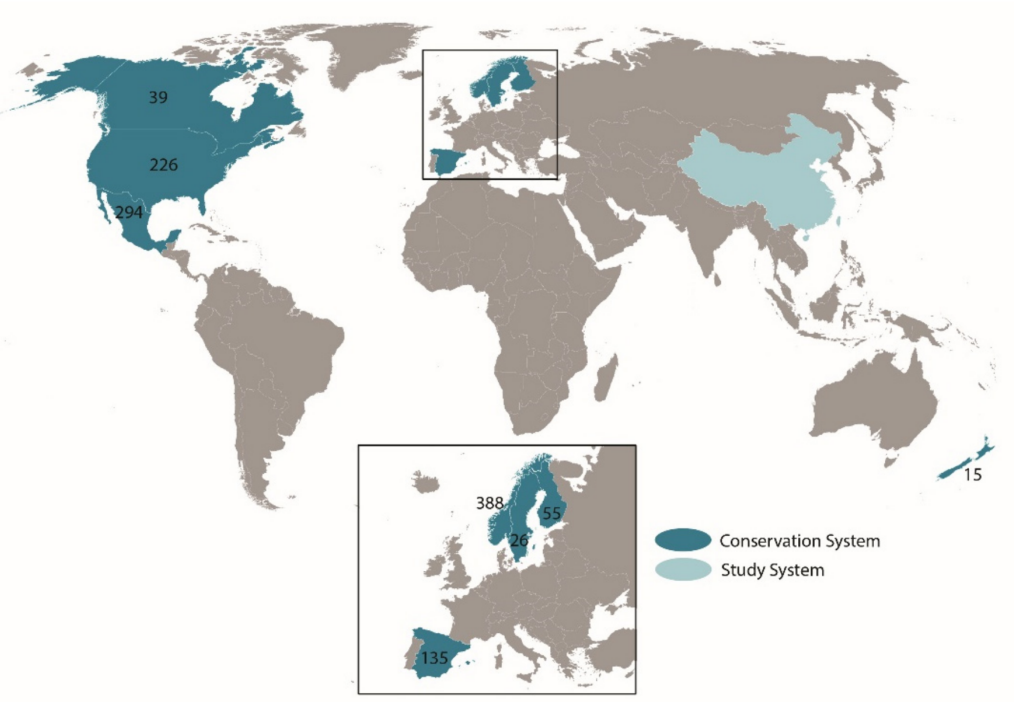

Figure 1. Of the 195 countries in the world, the United States, Canada, Mexico, Sweden, Norway, Finland, Spain, and New Zealand have national river conservation systems. China is studying the potential for system creation.

At the time the U.S. was finalizing the WSRA, New Zealand was embarking on its own campaign to establish a similar system designed to protect outstanding bodies of water and values including "fisheries, wildlife, cultural, recreational, wild, scenic, or scientific" [44]. In addition to these outstanding values, Indigenous Maori values were explicitly set out for protection under this policy, suggesting the Wild and Scenic policy can be used for what Ellis and Perry describe as an anticolonial policy for re-Indigenizing water resources [45]. It took roughly 14 years from 1967 for the Water and Soil Conservation Amendment Act of 1981, known colloquially as the Wild and Scenic Rivers legislation, to be passed in New Zealand. Today, 15 rivers are protected under this national legislation [44].

In Canada, the Canadian Heritage Rivers System (CHRS) is "a federal-provincialterritorial government program that works with community-level river stewardship groups to promote and conserve rivers with outstanding natural, cultural and recreational values" [46]. Currently, there are 39 designated rivers and 3 nominated for designation. However, unlike the U.S. WSRA that prohibits the degradation of a river's ORVs, a river may be de-designated in the CHRS if its values have been degraded or if the nominating 
province chooses to do so for purposes such as permitting dams or other hydraulic developments [47]. Arguably, the durability of this policy depends on vigilance of riverine communities and advocacy groups to ensure the maintenance of values and to challenge any proposed degazetting.

Due to the negative environmental legacy of dams in Norway, especially the impacts of these developments on the Indigenous Saami peoples, the country's parliament adopted four different policies between 1973 and 2009 to protect certain rivers from hydropower development. These policies are all tied to the Water Resources Act of 2001 and today protect 388 rivers, the most protections afforded in Europe to date [48-51]. Similarly, Finland's Rapids Protection Act of 1987 [51,52] and the Swedish Environmental Code of 1999 protect 55 and 26 wild rivers, respectively, against hydropower development. In Sweden, the law also mandates minimum environmental flows from existing hydropower plants and calls for the reassessment of old dams for retrofitting and removal [53,54].

River Protection Reserves (Reservas Naturales Fluviales) in Spain ensure that stretches of river with no to minimal human alteration be maintained in their natural status by maintaining flow and hydro-morphological characteristics, thus, restricting dams or diversions. Since its creation in 2015, 135 reserves have been established across the country. Due to the high level of alteration in downstream corridors, however, all these reserves exist in headwaters reaches [55-57].

The National Water Reserves for the Environment Program in Mexico is different from other examples of national river conservation systems in the sense that it focuses on river basins and environmental flows instead of protections on individual rivers. The National Water Reserves for the Environment Program (NWRP) protects river basins for 50-year increments based on environmental flow assessments. Environmental flows are important for protecting the biodiversity of these river basins and to help Mexico establish productive environmental water science and allocation practices. Today, there are roughly 294 Environmental Water Reserves (EWRs) already established (and the President has plans to designate another 150 by 2024), [58-60]. Nonetheless, an EWR designation alone does not prohibit dams from being built in the basins where a reserve is established. However, in practice, and along with complementary actions such as PA establishment or further regulations, once an EWR with a high relative volume of mean annual runoff is in place, it would be highly unlikely for a hydropower promotor to obtain a license. This is because the volume of mean annual runoff could decrease as a consequence of the dam. EWRs maintaining $80 \%$ of mean annual runoff volume or greater are a suitable indicator that dams could not feasibly be built, therefore, offering durable river protections that maintain free-flow (Sergio Salinas-Rodriguez, personal communication, 2 January 2021).

Currently, China is piloting a National Protected Rivers using the Qingzhu River, in Sichuan Province, southwest China, as a case study. These efforts are in response to the growing threats to the free-flow and water quality in rivers across the country due to rapid economic development since the 1970s [61]. This proposed system would take a holistic approach to the river's ecological integrity and authenticity, focusing on the treatment of water pollution, the ecological restoration of large rivers, and the protection of water sources on a national scale, unlike current localized actions for river protection. A national system in China would be beneficial due to the abundant river resources, recent awakening in environmental awareness, strong possibility for financial support, and efficiency in current governmental policies $[61,62]$.

\subsection{Decrees and Other Similar Executive Policies for Rivers}

Free-flowing river protections can also be implemented through executive decree or other similar legal frameworks. Regardless of a country's regime type (i.e., parliamentary, dictatorial, presidential, etc.), decrees are generally a secondary normative act that emanate from the executive branch of those who exercise administrative functions whether at the municipal, state, or federal level $[63,64]$. By ruling with a power delegated from the legislative, the executive chief can promote legal changes $[65,66]$. This unilateral power 
given to the executive office has an important role in the environmental agenda, in that it may allow protections to the environment that otherwise have no support from other branches [67]. An advantage of executive decrees or laws is the fact that, in comparison to conservation systems that can take years if not decades to establish (e.g., WSRs), these policy types can be implemented faster, providing urgent protections for threatened rivers. In this study, we found executive decrees or laws in six countries that safeguard rivers by offering protections against hydropower developments (See Table 2 and Figure 2). This includes establishing conservation reserves in important areas for biodiversity or implementing cultural site protections.

Table 2. Executive policies prohibiting dams exist in seven countries, though their policy types are distinct.

\begin{tabular}{cccc}
\hline Country & Rivers Protected & Year & Policy Type \\
\hline Slovenia & Soča and Tributaries & 1976 & National law \\
\hline Brazil & Cipó, São Francisco, Jequitinhonha, Grande, Pandeiros and Peruaçu & 2004 & State/provincial law \\
\hline \multirow{2}{*}{ India } & Bhagirathi & 1986 & Environment Act \\
& Koel Karo & 2010 & Gubernatorial Declaration \\
& Bedthi, Aghanashini, Kali, Shalmala & 2011 & Conservation Reserve \\
\hline Costa Rica & Shalmala & 2012 & Presidential Decree \\
& Savegre; Pacuare & 2015 & Presidential Decree \\
& Parismina & 2016 & National Institute \\
China & All rivers & 2020 & Moratorium \\
\hline Mexico & & & Dam halted \\
Zambia & Yangtze River & 2015 & Presidential Decree \\
\hline
\end{tabular}

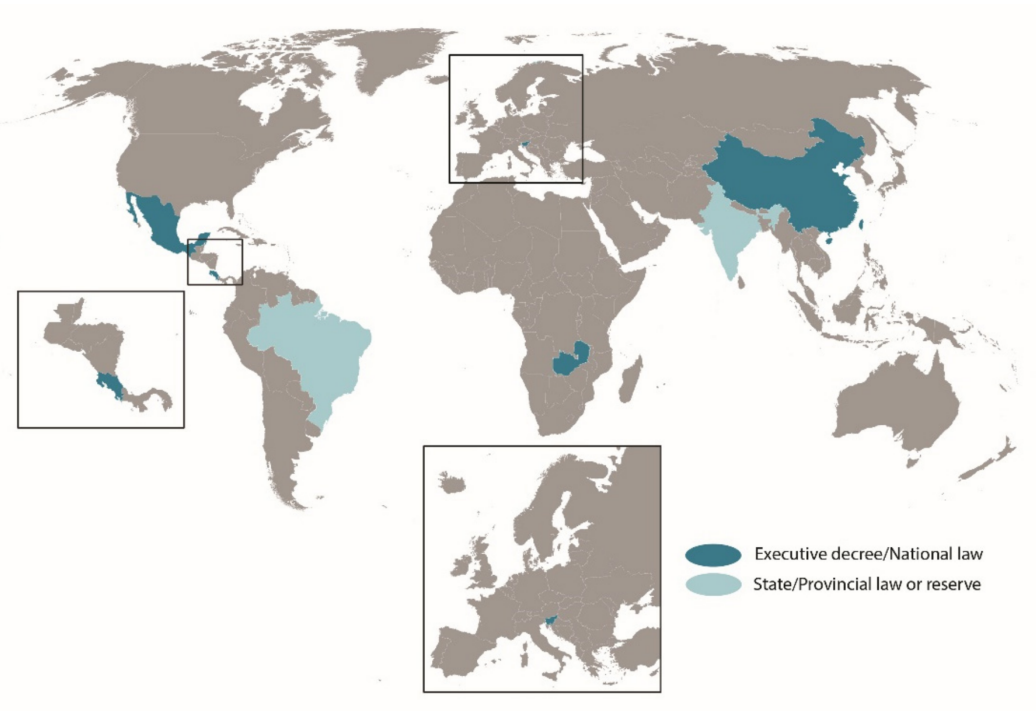

Figure 2. Executive decrees and laws are used in various locations to halt dam construction and set up reserves for freshwater, biodiversity, and cultural site protections.

In 1976, The Law on the Protection of the Soča River and Tributaries was implemented in Slovenia (then part of the former Yugoslavia) to halt hydropower developments that were rapidly increasing during the communist era [68,69]. Arguably the first durable protection implemented for river connectivity in Europe, this law has effectively protected the Soča River since its establishment, despite renewed pressures for hydropower development [51]. 
In India, the only explicitly protected free-flowing river is the Bhagirathi, protected by the 1986 Environmental Protection Act. However, in 2010 the governor of Jharkhand state declared the end of a dam construction project on the Koel Karo River after longstanding protests [70]. An amendment to the Indian Wildlife (Protection) Act, 1972, allowed for the creation of conservation reserves, some of which can protect a river's free-flow. The Aghanashini-Lion Tailed Macaque Conservation Reserve, Bedthi Conservation Reserve, and Hornbill Conservation Reserve, along the Bedthi, Aghanashini, and Kali Rivers, were established in 2011 to protect biodiversity in some of the Western Ghat's last free-flowing rivers. The protections limit any further dam development in the basins. Similarly, Shalmala River Riparian Conservation Reserve was established shortly thereafter to preserve the outstanding cultural value of the river, a place where rock carvings illustrate the deep spiritual connection of communities to the river [71]. These protections in the Western Ghats are critically important for the regional biodiversity. The Western Ghats, recognized as a global biodiversity hotspot, contains $30 \%$ of species of all major plant and animal groups found in India, despite representing only $6 \%$ of the total land area of India. However, 871 dams had been constructed in the Western Ghats by 2000 . Almost $16 \%$ of freshwater species assessed by IUCN are threatened with extinction, and another $10.5 \%$ are "data deficient", so might also be threatened [72].

In response to many years of Indigenous and conservation advocate opposition to proposed dams in the Rio Pacuare and Rio Savegre in Costa Rica, the hydropower capital of Central America also known for its whitewater tourism [73], then President Solis implemented decrees to halt dam construction for 25 years [74-77]. In January of 2020, this protection was layered by a national moratorium set forth by the National Energy Institute (Instituto Nacional de Electricidad) to halt all new hydropower development for seven years. This new national policy was made over concerns of exorbitant debt to international development banks for the construction of numerous large hydropower projects coupled with the reality that the country had maintained an energy surplus since 2008 despite growth projections to the contrary $[78,79]$. While not a durable protection in the sense that the policy will remain in place in the long-term, this moratorium certainly gives the country time to reconsider its river management priorities and perhaps to establish the national river conservation system long sought after by advocacy groups (Cordoba Molina, J.D., San Jose, Costa Rica, Personal Communication, 2020).

While not a national law, it is worth mentioning here the Permanent Preservation Rivers Law n 15.082 in Minas Gerais State of Brazil. Since 2004 this law effectively prohibits the modification of the beds and margins, sedimentation from resource extraction, and any activity that threatens to endanger aquatic biodiversity or the ecosystem balance of five important rivers: the Cipó, São Francisco, Pandeiros e Peruaçu, Jequitinhonha, and Grande [80]. Such comprehensive protections can be used as an example for policy development elsewhere in Brazil, should other states or the country care to pursue them.

In China, amid concerns over potential biodiversity loss in a protected area of the Yangstze, the Ministry of Environment halted construction of the Xiaonanhai hydropower project near Chongqing in 2015 [81]. The following year, President Xi Jinping decreed "No for great development, yes for great protection of the Yangtze River" [61], essentially setting the stage for curtailing any future dam developments on the river [82]. Similar to the motivations for studying the development of a national system of protected rivers, these actions result from a changing paradigm in Chinese water governance after decades of unfettered dam developments and other degrading activities on freshwater resources [61,62].

Expanding protections beyond the National Water Reserves System in Mexico, a presidential decree signed in 2018 specifically protects water resources of ten major river basins. In combination, these two policies aim to protect $55 \%$ of Mexico's surface water and, in so doing, it "will also improve the health and protection of 82 Natural Protected Areas, 64 Ramsar wetlands, and Mexico 's last free-flowing rivers" [83].

After a campaign initiated by WWF to protect one of the world's remaining freeflowing rivers, the Zambian Ministry of Energy halted the construction of Ndevu Gorge 
hydroelectric power plant in Luangwa river. More than 200,000 people joined the movement and signed a petition in a call for the river's legal protection, which was accepted after the pre-feasibility studies were cancelled by Zambian authorities [84]. A process to declare the Luangwa River a Water Resource Protection Area, under the umbrella of Water Resource Management Act No. 21 of 2011, is in progress. There is also an emerging advocacy to raise the awareness of implementing a National Integrated Water Infrastructure Plan that encompasses social and environmental needs $[85,86]$. Notably, this is the first case of durable river protection on the African continent.

\subsection{Rights of Rivers}

A major challenge in environmental law is persuading a judge that an individual has suffered enough environmental harm to have standing to sue a government or another person. One policy solution to address this challenge is a new form of legislation centered on the "Rights of Nature." It has developed as a legal process over the last 12 years, in response to the failure, in many instances, of modern environmental law to properly address the growing ecological crisis. It is founded on Indigenous traditions that treat humans as an integral part of nature rather than distinct from it [87]. Thus, it argues that instead of viewing nature as property to be owned, we should recognize that it has rights similar to those humans enjoy. Activists in the movement want the environment to be central in humanity's expanding moral circle [88]. Since non-human entities (e.g., trees, animals, rivers, etc.) cannot themselves bring action or appear in court, legal action can be achieved on the entity's behalf by a representing legal guardian. This type of representation increases protection of culturally significant aspects of the natural environment, as well as areas vulnerable to exploitation and pollution.

The Rights of Nature movements, and specifically the Rights of Rivers movements (See Table 3 and Figure 3)., have, since their inception, become rapidly evolving policy frameworks applied in several parts of the world. "Rights of Rivers" make it much easier to implement policies to protect rivers when they are recognized as living entities with inalienable rights [87]. While not all Rights of Nature cases explicitly protect the free-flowing nature of rivers, it can be argued that a dam proposal could be defeated by employing Rights of Nature. Here, we examine cases where Rights of Nature or Rights of Rivers are considered only in river specific cases.

South America plays a leading role in the Rights of Nature movement [87] with Ecuador being the first country to pioneer Rights for Nature as a constitutional right in 2008 [89]. The Articles of the Constitution state that Nature, or "Pacha Mama" has the right for respect for its existence and maintenance of its functions (Art. 71); to be restored (Art. 72); that the destruction of ecosystems and extinction of species shall be prevented (Art. 73); that people shall have the right to benefit from the environment and its natural wealth (Art. 74). This landmark legislation directly applied to rivers [90].

In the case of the Vilcabamba River, in 2011 the Provincial Government of Loja was accused of polluting the river with construction materials, which constricted the river channel and resulted in large floods that affected riverside populations. Since these environmental impacts were a violation of Rights for Nature, the Provincial Court of Justice of Loja granted a Constitutional injunction in favor of the river [90]. The court also determined that claims brought under provisions of the Rights of Nature should adopt a precautionary principle. Consequently, it would be the responsibility of those parties accused of damaging the environment to show that their activities were unlikely to be environmentally harmful [87]. While this case does not involve dams affecting free-flowing rivers, it does signify that rivers can be represented in court, laying the foundation for protection against dams should such threats arise. However, an important point from this case is that there were problems with the provincial government not fully complying with the protection order, highlighting the fact that good legislation for Rights of Nature is only as good as the process by which it is enforced [87]. 
Table 3. In just four years, rapidly expanding Rights of Rivers policies have been bestowed in six countries and campaigns to give other rivers such rights exist in four countries. Countries are listed in order of where they appear in the following discussion. The table does not include more general Rights of Nature actions (some of which are discussed in the text).

\begin{tabular}{ccc}
\hline Country & Policy & Year \\
\hline \multirow{2}{*}{ Ecuador } & Rights for Nature (constitutional) \\
Vilcabamba River & 2008 \\
New Zealand & Te Awa Tupua Act (Whanganui River) & 2011 \\
\hline Australia & Yarra River Protection Act & 2017 \\
\hline \multirow{2}{*}{ India } & Human rights for Ganges and Yamuna & 2017 \\
& Rivers & 2017 \\
& Himalayan Ecosystem & 2017 \\
\hline Colombia & Rio Atrato Basin Rights & 2017 \\
& Magdalena River & 2019 \\
& Coello, Combeima, and Cocora Rivers & 2019 \\
\hline USA & La Plata River & 2019 \\
\hline Bangladesh & Rights of Nature, Lamprey River & 2008 \\
\hline Nigeria & Klamath River (Yurok Tribal Council) & 2019 \\
\hline Chile & Rnake River (Nez Perce General Council) & 2020 \\
\hline Pakistan & Rights for the Boulder Creek Watershed & Campaign \\
\hline & River Ethiope Initiative & 2019 \\
\hline & “Free-Flowing Rivers” program & Campaign \\
\hline
\end{tabular}

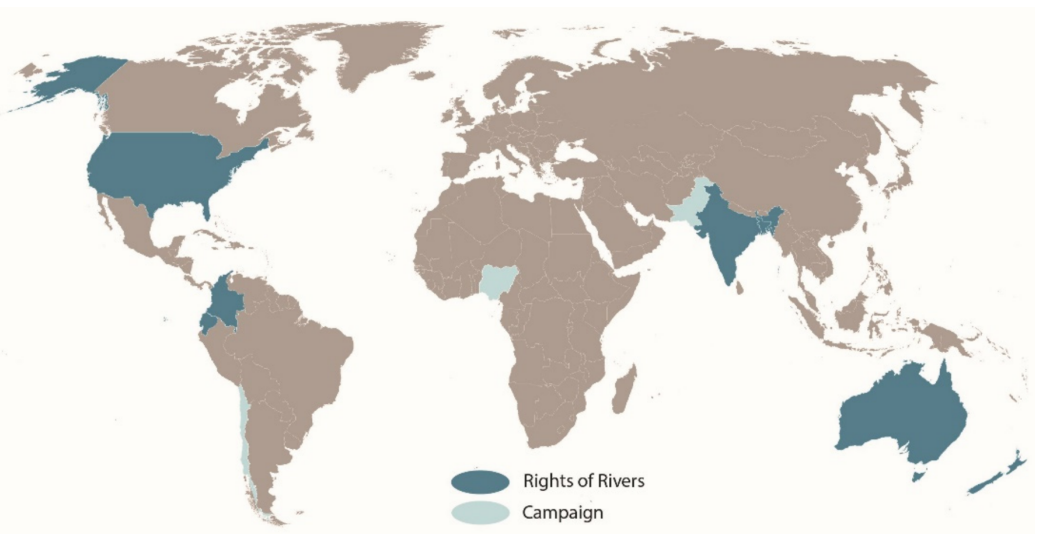

Figure 3. Rights of Rivers as a policy type is gaining traction on all inhabited continents except Europe. This map reflects the examples given in Table 3.

Since 2017, six countries have adapted the Rights of Nature concept to explicitly bestow Rights of Rivers through new policies. As this legal strategy is a relatively new concept, countries are taking lessons from others to improve the implementation of this durable protection instrument. Sam Bookman, of the Vance Center for International Justice elaborates that countries demonstrate similarities in the implementation of normative ecological values into law such as sustainable development, constitutional rights, precautionary principles, and public trusts [91]. These countries also translate the basic principles that underscore the Rights of Nature into concrete legal principles. A country's proposal for Rights of Rivers usually proceeds in a similar fashion, initially driven by the work of activists, and is then shaped by local stakeholder engagement, such as Indigenous communities. However, as noted below, there may be differences between countries in 
terms of the cultural and legal concepts that underlie proposals made for a river's rights how this policy is used, and how the status of the river is recognized [91].

New Zealand's Rights of Rivers, for instance, are implemented at the legislative and negotiation levels between government and Indigenous groups. The 2017 enactment of the Te Awa Tupua (Whanganui River Claims Settlement) took 15 years of negotiations between the government and the Whanganui River Māori Trust Board [87]. The Te Awa Tupua (meaning "the supernatural river") Act recognizes the Māori's long-held tenet that the Whanganui River is a living being, with whom they have an inseverable connection. Thus, Parliament passed legislation declaring that Te Awa Tupua - the river and all its physical and metaphysical elements-is an indivisible, living whole, and henceforth possesses "all the rights, powers, duties, and liabilities" of a legal person. While the river has these rights, the Act does not give an inclusive right for any person to sue on its behalf. The rights of the river are exercised instead by the Te Pou Tupua, which comprises one nominee from the local Indigenous guardians (the Tangata whenua) and one government nominee. The Te Pou Tupua represent the human face of the river [92] (p. 14) and can initiate legal proceedings to protect the Whanganui River if the River is damaged. The Te Awa Tupua Act transfers all government-owned land on the Whanganui riverbed to the management of the Te Pou Tupua, but it does not restrict existing private property rights or ownership of the water and wildlife [87].

Unlike the New Zealand and Ecuador cases, Australia's Yarra Protection Act does not grant legal personhood to the river. Therefore, the Yarra is not given independent legal status and does not have a legal guardian. Instead, the Birrarung Council advocates on behalf of the Yarra's protection and preservation [87]. The Council is an advisory body lacking legislative power to exercise the rights or take responsibility for any liabilities of the river [92] (p. 13). Nevertheless, the Council does have an important role in ensuring (as stated in the Yarra Protection Act) that decision-making is based on integration of environmental, social, and cultural considerations in support of public health and the environment. The Act also requires the development of a Yarra Strategic Plan for the river [87]. This plan is overseen by Melbourne Water, which acts independent of the Birrarung Council, ensuring that the Council is also free to serve as its own independent advisory body. Hence, while the Yarra Protection Act is technically not a Rights of Rivers approach like that of the Te Awa Tupua Act for the Whanganui, it is somewhat comparable [87]. The New Zealand and Australian statutes both recognize the river as a single living and integrated natural entity requiring protection; yet the values protected in the Te Awa Tupua Act are specifically Indigenous (Māori) oriented while the Yarra River Protection Act encompass not just Indigenous values, but also post-settlement cultural diversity and heritage, along with environmental, social, recreational, management, and general protection values [92]. These differences can also be found in other countries, such as in India, discussed below.

The Te Awa Tupua Act for the Whanganui is cited as the principle of Rights of Rivers in various other actions including two examples in India, in 2017. In the first, judges granted the right of the Ganges and Yamuna rivers and their tributaries as "legal and living entities having the status of a legal person with all corresponding rights, duties and liabilities" [93]. The case was based on the sacred importance of the rivers, personified as goddesses, in Hinduism. The court appointed three state government officials to act as legal custodians responsible for conserving and protecting the rivers and their tributaries [87]. Shortly thereafter a second case was made for granting personhood to the Himalayan ecosystem (the Himalayan Mountain Ranges, Glaciers, rivers, streams, rivulets, lakes, jungles, air, forests, meadows, dales, wetlands, grasslands, and springs) with the appointment of state, judicial, and local bar officers as guardians, with governance representation from local villages. The 2020 Rights for Rivers study notes some conceptual differences between these two examples. The case for the Ganges and Yamuna is founded principally on a spiritual and religious attachment to the rivers (and some concern has been expressed on such a heavy reliance). However, the Himalayan ecosystem case is based on a broader philosophy that brings together elements of both secular environmental and spiritual perspectives. 
Importantly, both cases were subsequently stayed by a decision of the Supreme Court later in 2017 [87].

The Te Awa Tupua Act also served as a model for establishing rights for the Atrato River in Colombia, which includes some of the most developed applications of Rights of Nature and the peoples' rights to a healthy environment [87]. The Rights of Nature framework in Colombia was developed in part through the Atrato River case [87,94] in which mining threatened its important biodiversity and Indigenous communities and cultures. Colombia's Constitutional Court declared that the Rio Atrato River basin has rights to "protection, conservation, maintenance and restoration" in a landmark verdict reached in November 2017 [94,95]. Highlighting biocultural rights, court ruling aims to protect the river while guaranteeing the fundamental rights of riverine communities on its banks, reasoning that conservation and restoration are the best ways to protect ethnic communities [95-97]. The court cited New Zealand's Te Awa Tupua model for the creation of a body, comprising representatives from government and local communities, to exercise legal guardianship over the river [87]. However, as noted with other case studies cited here, there appear to be significant challenges in the effective implementation of this legislation, in this case due to lack of funding and differences of opinions between the groups overseeing the protection of the river [87].

Several subsequent Rights of Rivers cases emerged in Colombia following the Atrato, including the Cauca River; the Magdalena River; the Coello, Combeima, and Cocora Rivers; and the La Plata River $[87,96]$. The Cauca and Magdalena River cases were responses to hydroelectric dam developments and their associated threats to riverine ecosystems or by other mismanagement (e.g., ineffective wastewater treatment). The case of the Coello, Combeima, and Cocora Rivers addressed the environmental impacts of gold mining. In all three cases, the courts recognized the rivers as legal subjects requiring "protection, conservation, maintenance and restoration" by state, municipal, and community entities [87]. All three cases also required a process of monitoring and reporting back of the results of any maintenance and restoration. The La Plata River case was in response to ineffective wastewater treatment and, as with the other cases noted above, called for the recognition of the river as a legal subject with protection measures in accordance with the rights of its guardians [98]. Rights of Rivers experts [87] note that, despite the strong role that Colombia has had in developing Rights of Nature, the application of the Rights of Rivers noted above tend to be focused on supporting human needs of the ecosystem rather than in support of the ecosystems themselves [87].

In the U.S., the Rights for Rivers approach has been adopted through Native American Tribal legislation. For example, the Yurok Tribe in California declared rights of personhood to the Klamath River and regulations to maintain its welfare. The resolution, passed by the tribal council in May 2019, was prompted by low water flows resulting in high rates of disease in salmon and cancellation of fishing seasons [99]. In 2020, the Nez Perce General Council passed a resolution recognizing the rights of the Snake River and calling for the creation of a legal guardianship body to represent the river's rights and interests. There has been at least one other effort to implement Rights of River legislation in the U.S. The Rights of Nature ordinance in Nottingham, New Hampshire, was developed in 2008 to prevent water withdrawal from the Lamprey River by a water bottling company [87]. While this was not tested in court, it did assist in a more general public campaign to halt the water bottling company.

Bangladesh has one of the most significant developments of Rights of Rivers in the recent past. It is the first country to recognize all rivers as having legal personhood, as of 2019 [100,101]. However, there are several other, important, ongoing campaigns in other parts of the world. In the U.S., the Earth Law Center has partnered with Boulder Rights of Nature (BRON) and other local partners to establish the Boulder Creek Watershed as a legal entity possessing rights. This is an ecologically and culturally important creek that faces threats to its water quality and flow. A local Rights of Nature law would permanently protect the Boulder Creek Watershed by establishing its fundamental rights, including a 
legal right to flow, to be free from pollution, and to restoration. It would also appoint legal guardians to enforce these rights [102].

In Nigeria, the Earth Law Center and the River Ethiope Trust Foundation (RETFON) launched an initiative to establish legal rights for the River Ethiope. The River Ethiope would be the first waterway in all of Africa to gain legal rights recognition. These groups seek rights for the River Ethiope to be free from pollution, for restoration, to native biodiversity, and more. The river would also have standing to be heard as a party in a court of law, and guardians would be appointed to enforce these rights [103,104]. This protection would be the second durable protection bestowed in Africa.

\subsection{Other Policy Options}

In modern political thought, Constitutional Laws are the highest domestic legal mechanism that set the ground rules of the government and the State apparatus $[105,106]$. They contain the fundamental norms of the State, its power structure, principles, objectives, guarantees, and parameters of the legal system that rules the country [106]. Constitutions also form a pact between those in power and society writ large; therefore, it must be a durable mechanism resisting random change [107]. As environmental degradation increases at a fast pace, countries are amending Constitutions in order to safeguard environmental rights. There are two foci of attention regarding the scope of such rights: the protection of the environment on its behalf, or as a human right [108].

Our analysis of the Constitute Database revealed among the extant 203 Constitutions, the term "environment" used in 154 Constitutions. Notably, the United Nations Environment Programme reported that 150 out of 195 recognized countries have environmental provisions in their Constitutions $[109,110]$, however, these are mostly rights that civil society is entitled to as a basic human need. Thus, we moved away from the anthropocentric general provisions of a healthy environment (i.e., the management of the bodies of water inside the State, navigation, human right to water for the present and future generations, water quality and quantity) to focus on the specific right of the river to be protected as free-flowing and/or subject to rights or legal personhood. We found that few countries provide constitutional provisions for rivers: Mexico and Scotland advise in favor of environmental flows, while Bolivia and Ecuador have provisions for Rights of Nature, as discussed in the section on Rights for Rivers. Cambodia and Lao People's Democratic Republic both mentioned aquatic ecosystems within specific articles, though there was no mention of river protections. Notwithstanding some consideration of riverine ecosystems, none of these constitutions reference the maintenance of free-flow or explicit restrictions on dam developments.

Aside from the Ecuadorian Rights of Nature case, the one constitution that explicitly prohibits the construction of dams is the Constitution of the Entre Rios (Between Rivers) Province of Argentina. This constitutional amendment was implemented in 2008, nearly 10 years after the state Antidam Law 9092 banned dam construction for the Paraná Medio Dam Project. The Entre Ríos Province Constitution was amended to add in Article 85, which requires protections against any large-scale infrastructure developments that would interrupt or degrade the free-flow of the Paraná and Uruguay rivers and the natural state of their associated ecosystems. The Constitution later extended protections to the Gualeguay River [111,112]. Albeit not a national constitution, this example heralds a potential for future constitutional amendments to include free-flowing river protections.

Environmental flows (e-flows) policy implementation is expanding rapidly since the Brisbane Declaration of 2007 that set out a global action agenda to protect and restore e-flows, or the "quantity, timing, and quality of freshwater flows and levels necessary to sustain aquatic ecosystems which, in turn, support human cultures, economies, sustainable livelihoods, and well-being" [113] (p. 4). Thus, beyond the biophysical needs of a riverine ecosystem, cultural values and social relations are additional factors that need to be incorporated into e-flow assessments [114]. Perhaps the greatest example of national e-flow legislation is the Mexican National Water Reserves system detailed previously that estab- 
lished protections for 294 river basins [58-60]. However, e-flow policies exist across the world from the United States [113] to North Africa [114] to southeastern Australia [115,116] to Spain [117,118], China [119], and beyond. In Europe, the Water Framework Directive calls for the implementation of e-flows, and a pan-European e-flows group has developed guidance that links to the European Habitats Directive [120,121]. Regarding free-flowing river protection, however, e-flows do not guarantee that dams will not be built. In fact, e-flows are often a mitigating strategy implemented along with dam construction or upon reevaluation of extant dam operations [115]. It is safe to say, however, that should e-flow minimum standards be implemented that stipulate a large percentage of the water remain in the river (say $\geq 75 \%$ ), any new dam construction would contradict those regulations.

Outstanding National Resource Waters (ONRW) in the United States is a provision of the Clean Water Act that offers additional protections to already designated areas such as "waters of National and State Parks, and wildlife refuges and waters of exceptional recreational or ecological significance" among others. The ONRW stipulates that only minor and temporary decreases in water quality are allowed in these waters. Due to the dramatic changes to water quality brought by dam construction and operation (e.g., changes in timing and quantity of sediment transport, temperature changes), ONRW designations can arguably be used to halt dam projects in rivers of particular conservation concern [122]. Such designations already exist in numerous states and tribal territories of the U.S. (e.g., New Mexico, Arizona, California, Colorado, Confederated Salish and Kootenai Tribes, Pueblo of Taos, Lac du Flambeau Band of Lake Superior Chippewa, Sokaogon Chippewa Community lands) while other states have not yet ventured to implement them [123]. This is another policy arena ripe for expansion.

State and Provincial wild and scenic-like conservation systems exist in the United States, and Australia. These systems were created as an alternative to federal regulations that some states felt were being imposed at the federal level. However, if a state so chooses, it can layer federal protections on the state protections, or vice versa. For instance, in Virginia and Ohio, rivers are only protected in the state system whereas in California and Oregon, some rivers are protected as federal WSR as well as state WSR [124,125]. In Puerto Rico, an unincorporated territory of the United States that is, nonetheless, subject to federal environmental legislation, there are WSRs as well as rivers protected at the local level in the Patrimonial Rivers Program (Programa Ríos Patrimoniales) established in 2014 [126]. In Australia, the national Wild Rivers Act of 2005 failed to pass. To ensure the free-flowing nature of significant rivers, regional governments took matters into their own hands creating the Queensland Wild Rivers Act, the Franklin and Gordon "wild rivers" in Tasmania, [127,128]. In the case of the Queensland Wild Rivers Act, however, it was overturned due to environmental injustices concerning Indigenous peoples coupled with development interests [128]. These cases make clear that it is possible to build on or circumvent national legislation in favor of state or provincial protections of free-flowing rivers if necessary to provide vital protections.

In this paper, we are not discussing PAs because these are rarely specifically focused on freshwater systems (see Introduction). "Ramsar sites" are an exception. These are wetland sites designated as Wetlands of International Importance according to specific criteria set out by the Ramsar Convention $[33,129]$. There are currently over 2400 Ramsar sites around the world, covering over 254 million hectares (note that this includes marine Ramsar sites). Countries that are contracting parties to the Ramsar Convention must designate at least one Ramsar site and are required to implement appropriate management plans for their listed wetlands. However, there is insufficient evidence to show that Ramsar sites are established based on a systematic basis, using best available biodiversity data and applying spatial planning tools [130]. Moreover, many of the selected sites are not effectively managed. In 2018, less than half of the Ramsar sites had management plans implemented [129]. Indeed, the Ramsar Convention does not have a mechanism of legal enforcement of its policies and there are no provisions for dealing with countries that breach their obligations. It has been described as a form of "soft law" and "countries have 
a moral compulsion rather than a legal obligation to uphold the Convention" (as cited in [131]). The compliance and enforcement of Ramsar obligations by its contracting parties has been noted as unsatisfactory [132]. Moreover, a central component of the Ramsar Convention is to support the "wise use" of wetlands, which is defined by the Convention as: "the maintenance of their ecological character, achieved through the implementation of ecosystem approaches, within the context of sustainable development" [133]. The Convention notes that wise use, therefore, "embraces conservation and sustainable use of wetlands and all the services they provide, for the benefit of people and nature." In practice, this means that some Ramsar sites may be managed in a way that allows development, for the benefit of people. Examples of where changes in natural flows through Ramsar sites have been implemented, to the detriment of the ecological character of the site, have been discussed for Australia [131]. Nevertheless, these are not faults of the underlying framework and concepts of the Ramsar Convention, but in the way that contracting parties chose to implement their obligations to the Convention. The Ramsar Convention is responsible for developing progressive and sustainable policies of wetland management among its growing numbers of contracting parties (currently 171) and has an essential role in placing wetland conservation and management centrally within political decisionmaking at the national and global scale [134].

\subsection{Active Campaigns}

As with the existing policy types detailed above, active campaigns for protection come about in large part due to advocacy efforts from affected groups and scientists. Aside from the Rights of Rivers campaigns or study systems highlighted in the previous sections, this study identified eight ongoing campaigns seeking the creation of permanent protections or halting river modification projects (See Table 4 and Figure 4). Five of these campaigns are related to protecting individual rivers (China, Colombia, Nepal, Peru, and Romania) while the other three are national or regional in nature. Here, we highlight just those in Europe to show how a combination of efforts could result in comprehensive free-flowing river protections and restoration efforts.

Table 4. Notable Durable River Protection campaigns and initiatives to create river conservation systems or protect individual rivers are currently taking place in Asia, Europe, and Latin America.

\begin{tabular}{ccc}
\hline Region & Country & River/Campaign Name \\
\hline Asia & China & Nu/Salween River [135] \\
\hline \multirow{2}{*}{ Europe } & Nepal & Save the Karnali River [136,137] \\
& Albania, Croatia, Serbia, Bosnia and \\
& Herzegovina, Slovenia, Montenegro & Save the Blue Heart [138] \\
\hline Latin America & Finland & Mating Belongs to All [139] \\
\cline { 2 - 3 } & Romania & Save Raul Alb [140] \\
\hline \multirow{2}{*}{ European Union } & Wild and Scenic-like System [51] \\
\hline & Colombia & Magdalena River [141] \\
\hline
\end{tabular}

Save The Blue Heart is one of the most publicized campaigns in its aims to protect the last remaining large concentration of Europe's free-flowing rivers from a boom in hydropower plants [28]. Located in the Balkan region of southeastern Europe, the Blue Heart is a biodiversity hotspot providing habitat for endangered species or subspecies like the Balkan lynx (Lynx lynx balcanicus) and Danube salmon (Hucho hucho) [136]. This campaign is concentrated on four key areas: the Vjosa River in Albania, the Mavrovo National Park in Macedonia, the Sava River in Slovenia, Croatia, Bosnia and Herzegovina, 
and Serbia, as well as the rivers of Bosnia and Herzegovina [136]. Save the Blue Heart seeks to raise public awareness about Balkan Rivers, their ecological values and vulnerability, stop dam projects in the four key areas, coordinate the development of a master plan with no-go areas for dam construction for all Balkan rivers, and improve knowledge about riverine biodiversity and the crucial role of biological connectivity and endemism in the region [136].

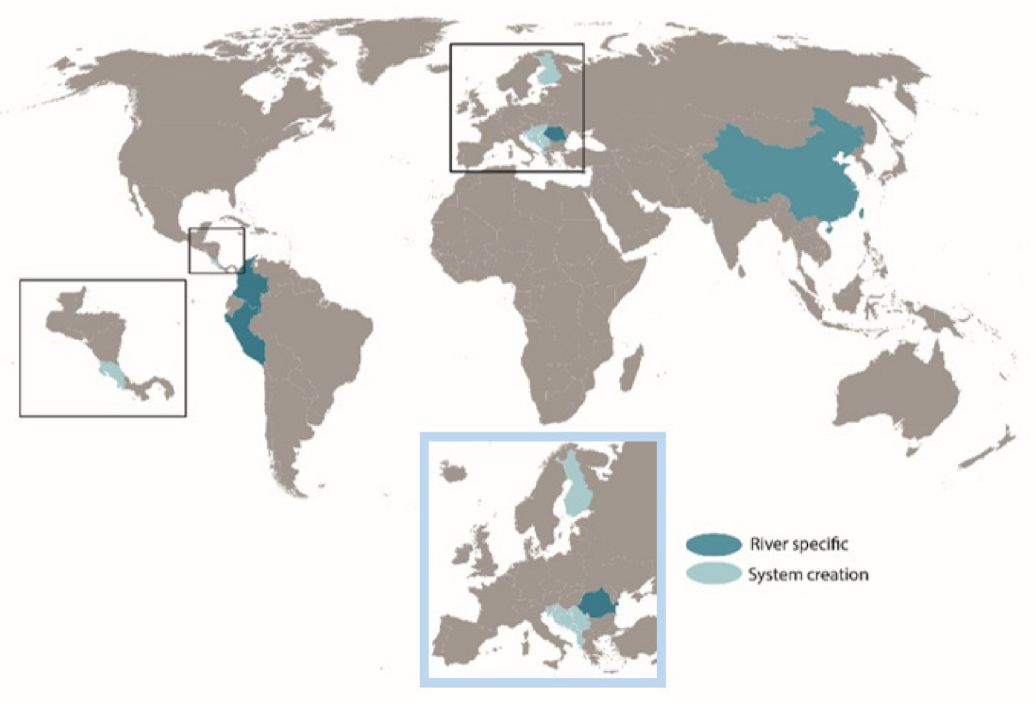

Figure 4. Despite growing calls for durable river protections, the global distribution of current campaigns to achieve free-flowing river protections is uneven and overall sparse. The inset box for Europe is shown in a blue frame because the whole region is experiencing a campaign to create a European Union policy based on the U.S. Wild and Scenic Rivers Act framework.

Beyond the scope of the Blue Heart, there is a growing movement across Europe advocating for the creation of a regional river conservation system based on the United States Wild and Scenic Rivers System [51,136]. Despite having protections for freshwater stipulated in the European Union's Water Framework Directive, there are no explicit protections for the preservation of a river's free-flow. Such a system would not only provide an avenue for protecting the Balkan rivers, but also rivers in Portugal, Austria, and Romania that are also facing dam threats [51]. Lacking a system, efforts like the Save Raul Alb in Romania [141] will have to pursue their campaigns on an individual basis. Moreover, advocates for the creation of a European system aim for this policy to include provisions stipulating the removal of outdated dams that block fish passage and other vital ecosystem services.

Dam removal and river restoration provide a "new" source of free-flowing river corridors for conservation purposes. For example, as more dam removals occur in Spain, the Reservas Naturales Fluviales can be extended into the newly restored segments of river, hence, providing an opportunity to expand durable protections there. These provisions would be similar to what the Finnish campaign, "Mating Belongs to All," advocates for: dam removal coupled with conservation efforts to benefit imperiled fish species [140]. If successful, the "Mating Belongs to All" campaign, coupled with Finland's National Rapids Protection Act, would greatly expand the number of free-flowing rivers protected in the country. Europe is seeing movements across scales and policy type, from decrees to system creation, to dam removal, though this region has yet to use Rights of Rivers.

\section{Discussion}

This study highlights three main types of policy mechanisms to achieve durable freeflowing rivers protections: (1) River Conservation Systems; (2) Executive Decrees and Laws; and (3) Rights of Rivers. Of the first of these, we have found that national river 
conservation systems have, thus far, been focused in North America, Europe, and Oceania. These systems represent useful models for refinement and application in other parts of the world. The WSRA of the U.S. has already provided a useful model framework from which other national river conservation systems have been developed.

Nevertheless, the existing national river systems are, not unsurprisingly, quite varied in the details in which they have been developed and implemented. Many countries place great significance on protecting natural processes of rivers within their national systems, including the National Water Reserves of Mexico, while others focus on outstanding river values like the U.S. Wild and Scenic Rivers Act, New Zealand's Wild and Scenic Rivers, and Canadian Heritage Rivers System. However, there are some general commonalities about these river conservation systems. They offer protections that are seemingly enforceable and durable and can be applied at the national or the state level. They also have the potential to expand with evolving national priorities for river governance. Thus, as countries look to further biodiversity protections and maintain river connectivity for climate resilience, extant national systems have the infrastructure already in place to include new rivers while other countries in the world may consider the establishment of such systems by drawing on lessons from places that have had those systems in place for decades.

Presidential decrees and similar policies have been implemented in several different parts of the world, including in more developing countries than have national river system protections. This study identifies the types of pressures and motivations for extending executive decrees for the protection of rivers. These range from Slovenia during a dam building rush to strengthen the communist agenda in the Balkans [69], to Costa Rica during a major push to develop energy for free trade and regional integration [73], to Mexico where the country aims to protect dwindling freshwater resources as populations grow and climate changes [58-60]. In these cases, as in others, proposed hydropower projects would flood sacred sites, major tourist destinations, ecosystems of particular biodiversity importance, and/or degrade vital freshwater resources. These decrees are generally effective for bestowing river protections while providing a window for the creation of permanent and/or broader protections. However, unlike national systems, decrees and similar policies focused on individual river protections generally lack explicit management plans for riverine ecosystems per se, and focus instead on halting dam construction alone. The main limitation of these decree protections is the small scale of the declaration. Many often fail to encompass more than just specific rivers or river sections. Some of these protections are time limited, as seen in Costa Rica where presidential decrees to halt dam construction on the Savegre and Pacuare rivers are stipulated for only 25 years instead of in perpetuity. For advocates and affected communities, that timescale means those who seek to permanently protect ecosystem services, homelands, and sacred sites will be in a constant campaign to stop the resurrected or next proposed development project.

Our study shows the growing importance of the Rights of Rivers movement, relative to some of the other protection systems discussed here. They have been implemented for different reasons. Nevertheless, they tend to be driven by Indigenous groups to protect rivers significant to their communities that were otherwise not receiving the desired attention or action from federal authorities to address threats. Thus, Rights of Rivers can be considered a powerful tool for recognizing Indigenous cultural plurality in legal systems, and for bringing about transformative change in the protection of nature. By engendering rivers to have standing in court, this act enables litigation grounded in new norms for both nature and Indigenous peoples alike. This new legal paradigm could serve as a model for non-Indigenous communities as well, as they are faced with dam threats, mining, or other degrading activities that threaten the integrity of the river. Indeed, some of the existing Rights of Rivers processes discussed here draw together broader aspects of environmental management with cultural value and guardianship.

Our analysis of Constitutional Laws provided relatively few examples. The Ecuadorian Rights of Nature (which formed part of constitutional law) and the Argentinian Entre Rios constitution cases are examples of how free-flowing river protections can be codified 
into the highest of national laws. Yet, generally around the globe, constitutions fall short of river specific protections. Perhaps as the need to protect freshwater resources, engender climate resilience, and safeguard biodiversity becomes more of a national concern, countries will capitalize on constitutional amendments to address these needs. However, given that constitutions are not meant to easily be changed, pursuing other policy options seems more likely. Hence, if countries, or even politically, socially, or ecologically constructed regions like the EU and the Amazon basin, care to protect in a meaningful way biodiversity and other riverine ecosystem services, governing bodies might consider river conservation systems or Rights of Rivers, as a durable protection policy option. It is also critical that protection policies can be implemented such that they are effective across biogeographic and ecological scales. While localized protections may serve as the foundation for future river protections, it is imperative that policies address the scale of river connectivity and international influences on river management.

Looking forward to how we can best develop durable protections into the future, a set of recommendations was recently published with the aim of ensuring that freshwater biodiversity is adequately safeguarded by the post-2020 Global Biodiversity Framework of the Convention on Biological Diversity (CBD), and the Biodiversity Strategy of the European Union (EU) [121]. These recommendations, which draw on aspects of EU's Water Framework Directive, include several components that align well with the concept of achieving durable river protections. For example, they include the recommendation to manage freshwater ecosystems at the catchment scale, and to ensure connectivity across multiple spatiotemporal scales and hydrological dimensions. It is also recommended that future policies should support research and management that enhance interactions between Integrated Water Resource Management (IWRM) (inclusive of effective e-flows) and ecological integrity, for freshwater biodiversity conservation. Consequently, these policies should encourage strategic planning in catchment management to balance human and wildlife water needs.

The recently published set of recommendations for safeguarding freshwater life beyond 2020 [121] also make several recommendations to the need to draw on good science in terms of using on novel research methods and data sources, as well as utilizing global assessment data. A review of the practical impact of publications in the journal Aquatic Conservation: Marine and Freshwater Ecosystems on conservation action showed that one of the most effective methods of achieving changes to management regimes is by "giving environmental managers the confidence to make defensible decisions based on sound scientific evidence" [144]. The recommendations for safeguarding freshwater life beyond 2020 [121] also note the importance of applying the "systems-thinking" approach to the development of conservation strategies, which recognizes that freshwater habitats are complex systems whose functions are closely integrated with other socioecological systems. The importance of this approach has been recognized in the growing body of work focused on coupled human-natural systems [145] and increased funding to support such work (e.g., from National Science Foundation Programs in the U.S.). This integration of natural and social science disciplinary work will be critical for developing and implementing new river protection mechanisms. Just as important is the process of ensuring that natural and social scientists, conservation practitioners, and other parties who are responsible for developing recommendations for river protections, work with the stakeholders and user groups who have a role in implementing and supporting these policies (e.g., policymakers, managers, and local community groups or other advocacy groups). This process of bringing together different sources of expertise and perspectives from different groups is a mechanism of "knowledge coproduction" that brings many benefits, ranging from building trust and collaboration between different parties, integration of knowledge, and refinement of perspectives, which ultimately produces a better informed, and more efficient and implementable set of protection policies $[146,147]$. This process of knowledge coproduction is goal driven, focused on specific outcomes, which is extremely important for the durability of protection mechanisms. A criticism of many activist campaigns is that 
they focus strongly on raising awareness only, without explicit information on defining actionable and achievable calls to action [148]. Protection campaigns and policies must have a theory of change that they are working towards.

In conclusion, this study aimed to present the current status of free-flowing river protection mechanisms around the globe. However, as policy is always changing, it may be that new cases of rights of river or new campaigns to halt development are emerging as you read this text. We do not guarantee the list is exhaustive, however, it does provide a baseline of information that may inform more geospatially focused and politically focused decision-making. Regardless of policy type, one thing is clear-protections for free-flowing rivers are in short supply. As countries move to create such protections to meet global calls, whatever policy mechanism they choose, must be tailored to the individual political and ecological geographies for them to address the specifics of local or regional conditions and stakeholder needs, to be effective and durable [149].

Author Contributions: Conceptualization, D.P.; methodology, D.P., S.F.; formal analysis, S.F., D.P.; data curation, S.F., D.P.; writing—original draft preparation, S.F., S.B., A.N., D.P., I.H.; writingreview and editing, D.P., I.H.; visualization, D.P.; supervision, D.P.; project administration, D.P. All authors have read and agreed to the published version of the manuscript."

Funding: This research received no external funding.

Institutional Review Board Statement: Not applicable.

Informed Consent Statement: Not applicable.

Data Availability Statement: Data sharing not applicable. No new data were created or analyzed in this study. Data sharing is not applicable to this article.

Acknowledgments: The authors are grateful to Mary DeJong (NAU Cline Library) for her assistance in literature reviews and locating published materials. We also appreciate the preliminary database compilation efforts made by NAU SES research assistant, Sarah E. Smith.

Conflicts of Interest: The authors declare no conflict of interest.

\section{References}

1. Addams, L.; Boccaletti, G.; Kerlin, M.; Stuchtey, M. Charting Our Water Future. Economic Frameworks to Inform Decision-Making. Available online: https://www.mckinsey.com/ \{\}/media/mckinsey/dotcom/client_service/sustainability/pdfs/charting\%20 our\%20water\%20future/charting_our_water_future_full_report_.ashx (accessed on 21 January 2021).

2. Russi, D.; Ten Brink, P.; Farmer, A.; Badura, T.; Coates, D.; Förster, J.; Kumar, R.; Davidson, N. The Economics of Ecosystems and Biodiversity for Water and Wetlands. Available online: https:/ /www.cbd.int/financial/values/g-ecowaterwetlands-teeb.pdf (accessed on 21 January 2021).

3. Vujica, Y. Water and Civilization. Water Int. 1992, 17, 163-171. [CrossRef]

4. Worster, D. Rivers of Empire; Oxford University Press: New York, NY, USA, 1985.

5. Dudgeon, D.; Arthington, A.H.; Gessner, M.O.; Kawabata, Z.I.; Knowler, D.J.; Lévêque, C.; Naiman, R.J.; Prieur-Richard, A.-H.; Soto, D.; Stiassny, M.L.J.; et al. Freshwater biodiversity: Importance, threats, status and conservation challenges. Biol. Rev. Camb. Philos. Soc. 2006, 81, 163-182. [CrossRef] [PubMed]

6. Reid, A.J.; Carlson, A.K.; Creed, I.F.; Eliason, E.J.; Gell, P.A.; Johnson, P.T.; Kidd, K.A.; MacCormack, T.J.; Olden, J.D.; Ormerod, S.J.; et al. Emerging threats and persistent conservation challenges for freshwater biodiversity. Biol. Rev. 2019, 94, 849-873. [CrossRef]

7. Tickner, D.; Opperman, J.; Abell, R.; Acreman, M.; Arthington, A.; Bunn, S.; Cooke, S.; Dalton, J.; Darwall, W.; Edwards, G.; et al. Bending the Curve of Global Freshwater Biodiversity Loss-An Emergency Recovery Plan. BioScience 2020, 70, 330-342. [CrossRef]

8. Darwall, W.; Bremerich, V.; De Wever, A.; Dell, A.I.; Freyhof, J.; Gessner, M.O.; Grossart, H.P.; Harrison, I.; Irvine, K.; Jähnig, S.C.; et al. The Alliance for Freshwater Life: A global call to unite efforts for freshwater biodiversity science and conservation. Aquat. Conserv. Mar. Freshw. Ecosyst. 2018, 28, 1-8. [CrossRef]

9. . Poff, N.L.R.; Allan, J.D.; Bain, M.B.; Karr, J.R.; Prestegaard, K.L.; Richter, B.D.; Sparks, R.E.; Stromberg, J.C. The natural flow regime: A paradigm for river conservation and restoration. BioScience 1997, 47, 769-784. [CrossRef]

10. Opperman, J.J.; Moyle, P.B.; Larsen, E.W.; Florsheim, J.L.; Manfree, A.D. Floodplains: Processes and Management for Ecosystem Services; University of California Press: Berkeley, CA, USA, 2017.

11. Costanza, R.; D’Arge, R.; De Groot, R.; Farber, S.; Grasso, M.; Hannon, B.; Limburg, K.; Naeem, S.; O’Neill, R.V.; Paruelo, J.; et al. The value of the world's ecosystem services and natural capital. Nature 1997, 387, 253-260. [CrossRef] 
12. Deinet, S.; Scott-Gatty, K.; Rotton, H.; Twardek, W.M.; Marconi, V.; McRae, L.; Baumgartner, L.J.; Brink, K.; Claussen, J.E.; Cooke, S.J.; et al. The Living Planet Index (LPI) for Migratory Freshwater Fish-Technical Report. Available online: https: //worldfishmigrationfoundation.com/wp-content/uploads/2020/07/LPI_report_2020.pdf (accessed on 28 January 2021).

13. World Wildlife Fund. Adeep Dive into Freshwater: Living Planet Report. 2020. Available online: https://f.hubspotusercontent20. net/hubfs/4783129/LPR/PDFs/Living_Planet_Report_Freshwater_Deepdive.pdf (accessed on 27 January 2021).

14. Grill, G.; Lehner, B.; Lumsdon, A.E.; MacDonald, G.K.; Zarfl, C.; Liermann, C.R. An index-based framework for assessing patterns and trends in river fragmentation and flow regulation by global dams at multiple scales. Environ. Res. Lett. 2015, $10,015001$. [CrossRef]

15. Best, J. Anthropogenic Stresses on the World 's Big Rivers. Nat. Geosci. 2019, 12, 7-21. [CrossRef]

16. Opperman, J.; Baruch-Mordo, S.; Carvallo, J.; Kammen, D.; Kiesecker, J.; Weber, C. Sustaining the Last Rivers. Am. Sci. 2019, 107, 302. [CrossRef]

17. Richter, B.D.; Postel, S.; Revenga, C.; Scudder, T.; Lehner, B.; Churchill, A.; Chow, M. Lost in development's shadow: The downstream human consequences of dams. Water Altern. 2010, 3, 14-42.

18. Winemiller, K.O.; McIntyre, P.; Castello, L.; Fluet-Chouinard, E.; Giarrizzo, T.; Nam, S.; Baird, I.G.; Darwall, W.; Lujan, N.K.; Harrison, I.; et al. Hydropower expansion in the Amazon, Congo and Mekong-A looming threat to global biodiversity. Science 2016, 351, 128-129. [CrossRef] [PubMed]

19. Albert, J.S.; Destouni, G.; Duke-Sylvester, S.M.; Magurran, A.E.; Oberdorff, T.; Reid, R.E.; Winemiller, K.O.; Ripple, W.J. Scientists' warning to humanity on the freshwater biodiversity crisis. Ambio 2020, 50, 85-94. [CrossRef]

20. Dugan, P.J.; Barlow, C.; Agostinho, A.A.; Baran, E.; Cada, G.F.; Chen, D.; Cowx, I.G.; Ferguson, J.W.; Jutagate, T.; Mallen-Cooper, M.; et al. Fish Migration, Dams, and Loss of Ecosystem Services in the Mekong Basin. Ambio 2010, 39, 344-348. [CrossRef]

21. Barbarossa, V.; Schmitt, R.J.P.; Huijbregts, M.A.J.; Zarfl, C.; King, H.; Schipper, A.M. Impacts of current and future large dams on the geographic range connectivity of freshwater fish worldwide. Proc. Natl. Acad. Sci. USA 2020, 117, 3648-3655. [CrossRef] [PubMed]

22. Chowdhury, A.R.; Kipgen, N. Deluge amidst conflict: Hydropower development and displacement in the North-east region of India. Prog. Dev. Stud. 2013, 13, 195-208. [CrossRef]

23. Galipeau, B.A.; Ingman, M.; Tilt, B. Dam-Induced Displacement and Agricultural Livelihoods in China's Mekong Basin. Hum. Ecol. 2013, 41, 437-446. [CrossRef]

24. Fearnside, P.M. Do hydroelectric dams mitigate global warming? The case of Brazil's Curuá-Una Dam. Mitig. Adapt. Strateg. Glob. Chang. 2005, 10, 675-691. [CrossRef]

25. Deemer, B.R.; Harrison, J.A.; Li, S.; Beaulieu, J.J.; DelSontro, T.; Barros, N.; Bezerra-Neto, J.F.; Powers, S.M.; dos Santos, M.A.; Vonk, J.A. Greenhouse Gas Emissions from Reservoir Water Surfaces: A New Global Synthesis. BioScience 2016, 66, 949-964. [CrossRef]

26. Räsänen, T.A.; Varis, O.; Scherer, L.; Kummu, M. Greenhouse gas emissions of hydropower in the Mekong River Basin. Environ. Res. Lett. 2018, 13. [CrossRef]

27. Grill, G.; Lehner, B.; Thieme, M.; Geenen, B.; Tickner, D.; Antonelli, F.; Babu, S.; Borrelli, P.; Cheng, L.; Crochetiere, H.; et al. Mapping the world's free-flowing rivers. Nature 2019, 569, 215-221. [CrossRef]

28. Zarfl, C.; Lumsdon, A.E.; Berlekamp, J.; Tydecks, L.; Tockner, K. A global boom in hydropower dam construction. Aquat. Sci. 2015, 77, 161-170. [CrossRef]

29. How Dams Damage Rivers. Available online: https://www.americanrivers.org/threats-solutions/restoring-damagedrivers/how-dams-damage-rivers / ?gclid=CjwKCAjw_Y_8BRBiEiwA5MCBJtwNKr7_gXxbJ0U13PzOSy1HlJPMj71Z7gALrRgs0 -GMztFum1fh1hoCD9oQAvD_BwE (accessed on 30 December 2020).

30. List of Motions. Available online: https://www.iucncongress2020.org/assembly/motions (accessed on 14 January 2021).

31. Hermoso, V.; Abell, R.; Linke, S.; Boon, P. The role of protected areas for freshwater biodiversity conservation: Challenges and opportunities in a rapidly changing world. Aquat. Conserv. Mar. Freshw. Ecosyst. 2016, 26, 3-11. [CrossRef]

32. Coad, L.; Burgess, N.D.; Loucks, C.; Fish, L.; Scharlemann, J.P.; Duarte, L.; Besançon, B. The Ecological Representativeness of the Global Protected Area Estate in 2009: Progress Toward the CBD 2010 Target. In UNEP-WCMC, WWFUS and ECI; University of Oxford: Oxford, UK, 2009.

33. Pittock, J.; Finlayson, M.; Arthington, A.H.; Roux, D.; Matthews, J.H.; Biggs, H.; Harrison, I.; Blom, E.; Flitcroft, R.; Froend, R.; et al. Managing freshwater, river, wetland and estuarine protected areas. In Protected Area Governance and Management; Worboys, G.L., Lockwood, M., Kothari, A., Feary, S., Pulsford, I., Eds.; ANU Press: Canberra, Australia, 2015; pp. 569-608.

34. Abell, R.; Lehner, B.; Thieme, M.; Linke, S. Looking Beyond the Fence line: Assessing Protection Gaps for the World's Rivers. Conserv. Lett. 2017, 10, 384-394. [CrossRef]

35. Juffe-Bignoli, D.; Brooks, T.M.; Butchart, S.H.M.; Jenkins, R.B.; Boe, K.; Hoffmann, M.; Angulo, A.; Bachman, S.; Böhm, M.; Brummitt, N.; et al. Assessing the Cost of Global Biodiversity and Conservation Knowledge. PLoS ONE 2016, 11, e0160640. [CrossRef]

36. Abell, R.; Harrison, I.J. A boost for freshwater conservation Integrating freshwater and terrestrial conservation planning has high returns. Science 2020, 370, 38-39. [CrossRef]

37. Thieme, M.L.; Khrystenko, D.; Qin, S.; Golden Kroner, R.E.; Lehner, B.; Pack, S.; Tockner, K.; Zarfl, C.; Shahbol, N.; Mascia, M.B. Dams and protected areas: Quantifying the spatial and temporal extent of global dam construction within protected areas. Conserv. Lett. 2020, 13. [CrossRef] 
38. Golden Kroner, R.E.; Qin, S.; Cook, C.N.; Krithivasan, R.; Pack, S.M.; Bonilla, O.D.; Cort-Kansinally, K.A.; Coutinho, B.; Feng, M.; Garcia, M.I.M.; et al. The uncertain future of protected lands and waters. Science 2019, 364, 881-886. [CrossRef]

39. Constitute. Available online: https:/ / www.constituteproject.org/ (accessed on 30 December 2020).

40. Wild and Scenic Rivers. Public Law 90-542, U.S.C 1271 et seq. 1968. Available online: https://uscode.house.gov/view.xhtml? path=/prelim@title16/chapter28\&edition=prelim (accessed on 21 February 2021).

41. Perry, D. Legible Rivers, Resilient Rivers: Lessons for Climate Adaptation Policy from the Wild and Scenic Rivers Act. Nat. Based Solut. Water Secur. 2021.

42. Perry, D.M. Reframing the Wild and Scenic Rivers Act for Ecosystem Based Resilience and Adaptation. Int. J. Wilderness 2017, 18, 41-48.

43. USA National Wild and Scenic Rivers. Available online: http:/ / www.rivers.gov/rivers/ (accessed on 12 January 2021).

44. Hughey, K.F.; Rennie, H.G.; Williams, N.J. New Zealand's 'wild and scenic rivers': Geographical aspects of 30 years of water conservation orders. N. Z. Geogr. 2014, 70, 22-32. [CrossRef]

45. Ellis, R.; Perry, D. A Confluence of Anticolonial Pathways for Indigenous Sacred Site Protection. J. Contemp. Water Res. Educ. 2020, 169, 8-26. [CrossRef]

46. Canadian Heritage Rivers System. Available online: https:/ / chrs.ca/en (accessed on 1 January 2021).

47. Blauwkamp, J.M.; Longo, P.J. Watering the Plains: Political Dynamics of River Preservation in Canada and the United States. Great Plains Res. 2002, 12, 353-368.

48. Paine, R. Dam a River, Damn a People? Saami (Lapp) Livelihood and the Alta/Kautokeino Hydro-Electric Project and the Norwegian Parliament; International Work Group for Indigenous Affairs: Copenhagen, Denmark, 1982.

49. Norway: Protection Plan for Watercourses and Master Plan for Hydropower Development. Available online: https: / archive. internationalrivers.org/zh-hans/node/16833 (accessed on 1 January 2021).

50. Securing a Future That Flows: Case Studies of Protection Mechanisms for Rivers. Available online: https://www.worldwildlife. org/publications/securing-a-future-that-flows-case-studies-of-protection-mechanisms-for-rivers (accessed on 1 January 2021).

51. Schäfer, T. Legal Protection Schemes for Free-Flowing Rivers in Europe-An Overview. Sustainability $2021,13$.

52. Häkkinen, K.; Karmala, P.; Ollila, M.; Paronen, J. Compensation Processes According to the Act on the Protection of Rapids and the Acts on Special Protection of the Rivers Ounasjoki and Kyrönjoki. Available online: https://helda.helsinki.fi/bitstream/ handle/10138/40618/SY_772.pdf (accessed on 21 January 2021).

53. Renöfält, B.M.; Jansson, R.; Nilsson, C. Effects of hydropower generation and opportunities for environmental flow management in Swedish riverine ecosystems. Freshw. Biol. 2010, 55, 49-67. [CrossRef]

54. Swedish Agency for Marine and Water Management. Towards Sustainable Hydropower in Sweden. Available online: https: // www.havochvatten.se/en/eu-and-international/towards-sustainable-hydropower-in-sweden.html (accessed on 31 October 2020).

55. Urquiaga Cela, R.; Martín Barajas, S. Reservas Naturales Fluviales en las Demarcaciones Hidrográficas Intercomunitarias e Intracomunitarias. Situación Actual y Propuestas Para 2017; Ministerio di Agricultura y Pesca, Alimentación y Medio Ambiente: Madrid, Spain, 2017.

56. Reservas Naturales Fluviales. Available online: https://www.miteco.gob.es/es/ministerio/patrimonio/Reservas_fluviales.aspx (accessed on 1 January 2021).

57. Catálogo Nacional de Reservas Hidrológicas. Available online: https://www.miteco.gob.es/es/agua/temas/delimitacion-yrestauracion-del-dominio-publico-hidraulico/Catalogo-Nacional-de-Reservas-Hidrologicas/Default.aspx (accessed on 1 January 2021).

58. Gómez-Balandra, M.A.; Del Saldaña-Fabela, M.P.; Martínez-Jiménez, M. The Mexican Environmental Flow Standard: Scope, Application and Implementation. J. Environ. Prot. 2014, 5, 71-79. [CrossRef]

59. Salinas-Rodríguez, S.A.; Barrios-Ordóñez, J.E.; Sánchez-Navarro, R.; Wickel, A.J. Environmental flows and water reserves: Principles, strategies, and contributions to water and conservation policies in Mexico. River Res. Appl. 2018, 34, 1057-1084. [CrossRef]

60. Salinas-Rodríguez, S.A.; Sánchez-Navarro, R.; Barrios-Ordóñez, J.E. Frequency of occurrence of flow regime components: A hydrology-based approach for environmental flow assessments and water allocation for the environment. Hydrol. Sci. J. 2020. [CrossRef]

61. Li, P. Proposing a National Protected River System in China. Int. J. Wilderness 2017, 23, 64-70.

62. Li, P.; Zhang, Y.; Lu, W.; Zhao, M.; Zhu, M. Identification of Priority Conservation Areas for Protected Rivers Based on Ecosystem Integrity and Authenticity: A Case Study of the Qingzhu River, Southwest China. Sustainability 2020, 13, 323. [CrossRef]

63. Neto, O.A. The Presidential Calculus: Executive Policy Making and Cabinet Formation in the Americas. Comp. Political Stud. 2006, 39, 415-440. [CrossRef]

64. Di Pietro, M.S.Z. Direito Administrativo, 27th ed.; Editora Atlas: São Paulo, Brazil, 2014.

65. John, C.; Matthew, S. Executive Decree Authority; Cambridge University Press: New York, NY, USA, 1998.

66. Negretto, G.L. Government Capacities and Policy Making by Decree in Latin America. Comp. Political Stud. 2004, 37, 531-562. [CrossRef]

67. Cooper, P.J.; George, W. Bush, Edgar Allan Poe, and the use and abuse of presidential signing statements. Pres. Stud. Q. 2005, 35, 515-532. [CrossRef]

68. Soča Valley. Available online: https:/ /www.slovenia.info/en/places-to-go/attractions/soca-valley (accessed on 3 January 2021).

69. Creţan, R.; Vesalon, L. The Political Economy of Hydropower in the Communist Space: Iron Gates Revisited. Tijdschr. Voor Econ. Soc. Geogr. 2017, 108, 688-701. [CrossRef] 
70. The Koel Karo People's Movement in Eastern India. Available online: https://www.ritimo.org/The-Koel-Karo-People-sMovement-in-Eastern-India (accessed on 3 January 2021).

71. Free-Flowing Rivers the Soul of South Asia. Available online: http://hydrolab.io/ffr/\#7/34.407/-113.302/FFR-CNT-NME-CNNLKE (accessed on 1 January 2021).

72. Molur, S.; Smith, K.G.; Daniel, B.A.; Darwall, W.R.T. The Status and Distribution of Freshwater Biodiversity in the Western Ghats, India; IUCN: Cambridge, UK; Gland, Switzerland; Zoo Outreach Organisation: Coimbatore, India, 2011.

73. Perry, D.M.; Berry, K.A. Central American integration through infrastructure development A case study of Costa Rican hydropower. Reg. Cohes. 2016, 6, 96-115. [CrossRef]

74. After Rafting the Pacuare, President Solís Bans Hydroelectric Dams. Available online: http://ticotimes.net/travel/after-raftingthe-pacuare-president-solis-bans-hydroelectric-dams (accessed on 3 January 2021).

75. Comunidades Piden al Gobierno Decreto Para no Represar Ríos Pacuare y Savegre. Available online: https://www.elmundo.cr/ comunidades-piden-al-gobierno-decreto-para-no-represar-rios-pacuare-y-savegre/ (accessed on 9 May 2018).

76. Library, W. Gobierno Decretó Salvaguarda Ambiental de 25 Años Para Ríos Pacuare y Savegre-Presidencia de la República de Costa Rica. 2018. Available online: https:/ / presidencia.go.cr/comunicados/2015/08/gobierno-decreto-salvaguarda-ambientalde-25-anos-para-rios-pacuare-y-savegre-2/(accessed on 21 February 2021).

77. Moir, K.; Thieme, M.; Opperman, J. Securing a Future that Flows: Case Studies of Protection Mechanisms for Rivers. Available online: https: / / www.worldwildlife.org/publications/securing-a-future-that-flows--2 (accessed on 1 January 2021).

78. Proyectos Hidroeléctricos de H. Solís Agudizan la Crisis Financiera en el ICE. Available online: https: / www.informa-tico.com/ 14-03-2019/ proyectos-hidroelectricos-h-solis-agudizan-crisis-financiera-ice (accessed on 23 June 2020).

79. Acto Final Procedimiento Administrativo Ordinario de Resolucion de Contrato para la Compra de Energia Electrica, Cobro de Danos y Multas. Expediente OD-PHRB515. 2020.

80. Matos Da Cruz Correia, C.; Carvalho De Melo, M.; Pinheiro Santos, N.A. Sharing Experiences on the Waters of the Minas Gerais, Brazil. Available online: http:/ / portalinfohidro.igam.mg.gov.br/images/3CH002618_Experiencia_das_\%C3\%ADguas_Vol_1_ POR_Digital.pdf (accessed on 21 January 2021).

81. China Blocks Yangtze Dam Project, Activists Say. New York Times. 2015. Available online: https://www.nytimes.com/2015/04/ 11/world/asia/environmental-order-in-china-to-prevent-building-of-contested-dam.html (accessed on 10 April 2015).

82. Zhou, Y.M. The development of the Yangtze River Economic Zone highlights the "green" governance. People's Dly. $2016,3,7$.

83. Echeverria, M. Historic Presidential Decrees Safeguard Water Supplies for People and Nature in Close to 300 River Basins in Mexico. Available online: https:/ / www.worldwildlife.org/press-releases/historic-presidential-decrees-safeguard-watersupplies-for-people-and-nature-in-close-to-300-river-basins-in-mexico (accessed on 1 January 2021).

84. Zambia Halts Hydropower Dam on Luangwa River. Available online: https://wwf.panda.org/discover/our_focus/freshwater_ practice/freshwater_news/?349071/Zambia-halts-hydropower-dam-on-Luangwa-river (accessed on 16 January 2021).

85. Conservation of the Luangwa River Hydroelectric Dam Halted, Conservationists Delighted. Available online: https:// africageographic.com/stories/construction-luangwa-river-hydroelectric-dam-halted-conservationists-delighted/ (accessed on 27 January 2021).

86. Will Zambia's Luangwa River Be Dammed? Have You Say. Available online: https://africageographic.com/stories/will-zambiasluangwa-river-dammed/ (accessed on 27 January 2021).

87. Rights of Rivers: A Global Survey of the Rapidly Developing Rights of Nature Jurisprudence Pertaining to Rivers; The Cyrus R. Vance Center for International Justice: New York, NY, USA; Earth Law Center: Boulder, CO, USA; International Rivers: Berkeley, CA, USA, 2020.

88. Samuel, S. Bangladesh Gave All Its Rivers Legal Rights. Available online: https://www.vox.com/future-perfect/2019/8/18/20 803956/bangladesh-rivers-legal-personhood-rights-nature (accessed on 7 September 2020).

89. Legal Text of the Ecuadorian Constitution of 2008. Available online: http:/ / www.asambleanacional.gob.ec/sites/default/files/ documents / old/constitucion_de_bolsillo.pdf (accessed on 6 September 2020).

90. Ecuador Adopts Rights of Nature in Constitution. Available online: https:/ / therightsofnature.org/ecuador-rights / (accessed on 4 September 2020).

91. Rights of Rivers: Stories of Sovereignty and Guardianship in the Fight to Give Rivers Legal Rights-Webinar. Available online: https:/ / www.youtube.com/rightsofrivers (accessed on 11 January 2021).

92. O'Bryan, K. Indigenous Rights and River Rights: Australia and New Zealand. Available online: https://globalwaterforum.org/ 2018/06/07/indigenous-rights-and-river-rights-australia-and-new-zealand/ (accessed on 2 September 2020).

93. Safi, M.; Agencies. Ganges and Yamuna Rivers Granted Same Legal Rights as Human Beings. Available online: https://www. theguardian.com/world/2017/mar/21/ganges-and-yamuna-rivers-granted-same-legal-rights-as-human-beings (accessed on 4 September 2020).

94. Vargas-Chaves, I.; Rodríguez, G.A.; CumbeFigueroa, A.; Mora-Garzón, S.E. Recognizing the Rights of Nature in Colombia: The Atrato River case. Rev. Jurídicas 2020, 17, 13-41. [CrossRef]

95. Colombian Constitutional Court Sets a Global Precedent. Available online: https://www.abcolombia.org.uk/constitutionalcourt-sets-global-precedent/ (accessed on 4 September 2020). 
96. Moloney, A. The Colombian Amazon Now Has the Same Legal Rights as You. Available online: https://www.weforum. org/agenda/2018/04/colombias-top-court-orders-government-to-protect-amazon-forest-in-landmark-case/ (accessed on 4 September 2020).

97. Center for Social Justice Studies et al. v. Presidency of the Republc et al. Judgment T-622/16-Constitutional Court of Colombia (10 November 2016) The Atrato River Case. Available online: http:/ / files.harmonywithnatureun.org/uploads/upload838.pdf (accessed on 21 January 2021).

98. Juzgado Unico Civil Municipal La Plata-Huila. Available online: http:/ / files.harmonywithnatureun.org/uploads/upload823.pdf (accessed on 21 January 2021).

99. Smith, A.V. The Klamath River Now Has the Rights of a Human. Available online: https://www.hcn.org/issues/51.18/tribalaffairs-the-klamath-river-now-has-the-legal-rights-of-a-person (accessed on 12 September 2020).

100. Westerman, A. Should Rivers Have Same Legal Rights as Humans? A Growing Number of Voices Say Yes. Available online: https:/ / www.npr.org/2019/08/03/740604142/should-rivers-have-same-legal-rights-as-humans-a-growing-number-ofvoices-say-ye. (accessed on 2 September 2020).

101. Bangladesh Declares Its Rivers “Legal Persons”. Available online: https:/ /www.ctvnews.ca/world/bangladesh-declares-itsrivers-legal-persons-1.4490552 (accessed on 7 September 2020).

102. Boulder Creek. Available online: https:/ / www.earthlawcenter.org/boulder-creek (accessed on 26 January 2021).

103. River Ethiope Initiative. Available online: https:/ / www.earthlawcenter.org/river-ethiope (accessed on 11 January 2021).

104. River Defenders Launch Initiative to Secure Rights for the River Ethiope. Available online: https://www.earthlawcenter.org/elcin-the-news / 2018/4/river-defenders-launch-initiative-to-secure-rights-for-the-river-ethiope (accessed on 11 January 2021).

105. Loughlin, M. Constitutional Theory: A 25th Anniversary Essay. Oxf. J. Leg. Stud. 2005, 25, 183-202. [CrossRef]

106. Silva, J.A. Curso de Direito Constitucional Positivo, 38th ed.; Malheeiros Editores: São Paulo, Brazil, 2014; ISBN 978-85-392-0274-5.

107. Alexander, L. What are constitutions, and what should (and can) they do? Soc. Philos. Policy 2011, 28, 1-24. [CrossRef]

108. Daly, E.; May, J.R. Comparative environmental constitutionalism. Jindal Glob. Law Rev. 2015, 6, 9-30. [CrossRef]

109. May, J. Environmental Rights and Wrongs: Implementing Environmental Constitutionalism; University of Oslo Press: Olso, Norway, 2020.

110. UNEP. UNEP, UN Human Rights Office Sign New Agreement, Stepping Up Commitment to Protect the Human Right to a Healthy Environment. 2019. Available online: https://www.unenvironment.org/news-and-stories/press-release/unep-unhuman-rights-office-sign-new-agreement-stepping-commitment (accessed on 11 January 2021).

111. Esta Es La Nueva Constitucion De Entre Rios. Available online: http:/ / www.apfdigital.com.ar/despachos.asp?cod_des=112047 (accessed on 11 January 2021).

112. Cada 25 de Septiembre se Celebra “El Día de la Libertad de los Ríos. Available online: https://www.elmiercolesdigital.com.ar/ cada-25-de-septiembre-se-celebra-el-dia-de-la-libertad-de-los-rios/ (accessed on 11 January 2021).

113. Arthington, A.H.; Bhaduri, A.; Bunn, S.E.; Jackson, S.E.; Tharme, R.E.; Tickner, D.; Young, B.; Acreman, M.; Baker, N.; Capon, S.; et al. The Brisbane Declaration and Global Action Agenda on Environmental Flows. Environ. Sci. 2018, 6. [CrossRef]

114. O’Brien, G.C.; Dickens, C.; Baker, C.; Stassen, R.; van Weert, F. Sustainable Floodplains: Linking E-Flows to Floodplain Management, Ecosystems, and Livelihoods in the Sahel of North Africa. Sustainability 2020, 12, 10578. [CrossRef]

115. Poff, N.L.R.; Matthews, J.H. Environmental flows in the Anthropocence: Past progress and future prospects. Curr. Opin. Environ. Sustain. 2013, 5, 667-675. [CrossRef]

116. MDBMC: An Audit of Water Use in the Murray-Darling Basin; Murray-Darling Basin Ministerial Council: Canberra, Australia, 1995.

117. Belmar, O.; Velasco, J.; Martinez-Capel, F. Hydrological classification of natural flow regimes to support environmental flow assessments in intensively regulated Mediterranean rivers, Segura River Basin (Spain). Environ. Manag. 2011, 47, 992-1004. [CrossRef] [PubMed]

118. Ibáñez, C.; Caiola, N.; Belmar, O. Environmental Flows in the Lower Ebro River and Delta: Current Status and Guidelines for a Holistic Approach. Water 2020, 12, 2670. [CrossRef]

119. Zhang, Y.; Arthington, A.H.; Bunn, S.E.; Mackay, S.; Xia, J.; Kennard, M. Classification of flow regimes for environmental flow assessment in regulated rivers: The Huai River Basin, China. River Res. Appl. 2012, 28, 989-1005. [CrossRef]

120. European Commission. Ecological Flows in the Implementation of the Water Framework Directive. 2015. Available online: https: / circabc.europa.eu/sd/a / 4063d635-957b-4b6f-bfd4-b51b0acb2570/Guidance\%20No\%2031\%20-\%20Ecological\% 20flows\%20(final\%20version).pdf (accessed on 27 January 2021).

121. Van Rees, C.B.; Waylen, K.A.; Schmidt-Kloiber, A.; Thackeray, S.J.; Kalinkat, G.; Martens, K.; Domisch, S.; Lillebø, A.I.; Hermoso, V.; Grossart, H.-P.; et al. Safeguarding freshwater life beyond 2020: Recommendations for the new global biodiversity framework from the European experience. Conserv. Lett. 2020, e12771. [CrossRef]

122. Introduction to the Clean Water Act. Available online: https://cfpub.epa.gov/watertrain/moduleFrame.cfm?parent_object_id= 2569 (accessed on 4 January 2021).

123. EPA's Tier Three Waters for the Pesticide General Permit (PGP) (Outstanding National Resource Waters). Available online: https: //www.epa.gov/npdes/epas-tier-three-waters-pesticide-general-permit-pgp-outstanding-national-resource-waters (accessed on 26 January 2021).

124. Historic Wild \& Scenic Opportunity I Oregon Wild. (n.d.). Available online: https://oregonwild.org/rivers (accessed on 21 February 2021). 
125. Perry, D. The Uneven Geography of River Conservation in the U.S.: Insights from The Application of the Wild and Scenic Rivers. Act. Dissertation, University of Oregon, Eugene, OR, USA, 2016. Available online: https://pqdtopen.proquest.com/doc/194704 3200.html?FMT=ABS (accessed on 12 January 2021).

126. Programa Ríos Patrimoniales de Puerto Rico. Available online: http://drna.pr.gov/wp-content/uploads/formidable/ Designación-Rios-Patrimoniales.pdf (accessed on 17 September 2018).

127. Kingsford, R.T.; Roff, A. A Case Study: Floodplain Development on the Paroo River-The Last Free-Flowing River in the Murray-Darling Basin; Wetlands and Rivers Research Group, School of Biological, Earth and Environmental Sciences, University of NSW: Sydney, Australia, 2008.

128. Shah, S.H.; Rodina, L. Water ethics, justice, and equity in social-ecological systems conservation: Lessons from the Queensland Wild Rivers Act. Water Policy 2018, 20, 933-952. [CrossRef]

129. Ramsar Convention on Wetlands. Global Wetland Outlook: State of the World's Wetlands and Their Services to People. 2018. Available online: https://static1.squarespace.com/static/5b256c78e17ba335ea89fe1f/t/5b9ffd2e0e2e7277f629eb8f/1537211739 585/RAMSAR+GWO_ENGLISH_WEB.pdf (accessed on 27 January 2021).

130. Finlayson, C.M.; Arthington, A.H.; Pittock, J. Freshwater ecosystems in protected areas: A synthesis. In Freshwater Ecosystems in Protected Areas: Conservation and Management; Finlayson, C.M., Arthington, A.H., Pittock, J., Eds.; Routledge: Oxford, NY, USA, 2018; pp. 256-272.

131. Pittock, J.; Finlayson, C.M.; Gardner, A.; McKay, C. Changing character: The Ramsar Convention on Wetlands and climate change in the Murray-Darling Basin, Australia. Environ. Plan. Law J. 2010, 27, 401-425.

132. Baakman, K. Testing Times: The Effectiveness of Five International Biodiversity-Related Conventions. Ph.D. Thesis, Tilburg University, Tilburg Law School, Tilburg, The Netherlands, 9 September 2011.

133. Ramsar Convention Secretariat. Wise Use of Wetlands: Concepts and Approaches for the Wise Use of Wetlands. Ramsar Handbooks for the Wise Use of Wetlands, 4th ed.; Ramsar Convention Secretariat: Gland, Switzerland, 2010; Volume 1.

134. Bowman, M. The Ramsar Convention on Wetlands: Has it made a difference? In Yearbook of International Co-Operation on Environment and Development; Stokke, O.S., Thommessen, Ø.B., Eds.; Earthscan: London, UK, 2002; pp. 61-68.

135. Salween. Available online: https://www.internationalrivers.org/where-we-work/asia/salween/ (accessed on 16 January 2021).

136. Chamberlain, L. Eco-Masterplan for Balkan Rivers. Available online: https://balkanrivers.net/sites/default/files/Eco-Masterplan\% 20for\%20Balkan\%20Rivers-PRESS-REVISION\%201-2018\%20November\%2026-WEB.pdf (accessed on 21 January 2021).

137. Nepal River Conservation Trust. Available online: http:/ / www.nrct.org.np/ (accessed on 16 January 2021).

138. Save the Karnali. Available online: http:/ / www.karnaliriver.org/ (accessed on 16 January 2021).

139. The Balkan Rivers: Save the Blue Heart of Europe. Available online: https://www.balkanrivers.net/en/campaign (accessed on 16 January 2021).

140. K Group (Kesko and K-Store) and WWF Finland to Cooperate on Behalf of Endangered Migratory Fish: "Mating Belongs to All". Available online: https://www.kesko.fi/en/media/news-and-releases/news/2017/k-group-kesko-and-k-stores-andwwf-finland-to-cooperate-on-behalf-of-endangered-migratory-fish-mating-belongs-to-all/ (accessed on 21 January 2021).

141. Romania: Save the River Raul Alb. Available online: https:/ /riverwatch.eu/en/general/news/romania-save-river-raul-alb (accessed on 16 January 2021).

142. Andes. Available online: https:/ / www.internationalrivers.org/where-we-work/latin-america/andes/ (accessed on 16 January 2021).

143. Costa Rica. Comunidades, Movimiento Ríos Vivos y Ríos Libres Turrialba se Manifiestan Contra Proyectos Hidroeléctricos. Available online: https:/ / www.radiotemblor.org/ costa-rica-comunidades-movimiento-rios-vivos-y-rios-libres-turrialba-semanifiestan-contra-proyectos-hidroelectricos/ (accessed on 16 January 2021).

144. Boon, P.J.; Baxter, J.M. Putting publication into practice: A summary of the impact of selected articles published in Aquatic Conservation: Marine and Freshwater Ecosystems. Aquat. Conserv. Mar. Freshw. Ecosyst. 2020, 30, 1711-1718. [CrossRef]

145. Carter, N.H.; Viña, A.; Hull, V.; McConnell, W.J.; Axinn, W.; Ghimire, D.; Liu, J. Coupled human and natural systems approach to wildlife research and conserva-tion. Ecol. Soc. 2014, 19, 43. [CrossRef]

146. Cooke, S.J.; Nguyen, V.M.; Chapman, J.M.; Reid, A.J.; Landsman, S.J.; Young, N.; Hinch, S.G.; Schott, S.; Mandrak, N.E.; Semenuik, C.A.D. Knowledge co-prodcution: A pathway to effective fisheries management, conservation, and governance. Fisheries 2020. [CrossRef]

147. Norström, A.V.; Cvitanovic, C.; Löf, M.F.; West, S.; Wyborn, C.; Balvanera, P.; Bednarek, A.T.; Bennett, E.M.; Biggs, R.; de Bremond, A.; et al. Principles for knowledge co-production in sustainability research. Nat. Sustain. 2020, 3, 182-190. [CrossRef]

148. Christiano, A.; Neimand, A. Stop Raising Awareness Already. 2017. Available online: https://ssir.org/articles/entry/stop_ raising_awareness_already (accessed on 27 January 2021).

149. Vollmer, D.; Harrison, I.J. $\mathrm{H}_{2} \mathrm{O} \neq \mathrm{CO}_{2}$ : Framing and responding to the global water crisis. Environ. Res. Lett. 2021, 16. [CrossRef] 